\title{
Jurisdiction, Choice of Law and Enforcement of Foreign Judgments
}

\author{
D A V I K E N Y
}

\subsection{Introduction}

The experience of Brexit has shown that it is fractal in its complexity: figure out one highly complex issue and it will expose another issue, of equal complexity, beneath it. One of these - that has not received a great deal of attention in the process ${ }^{1}-$ is private international law, or the conflict of laws: the rules that govern international private law litigation. ${ }^{2}$ This body of law comprises the rules of jurisdiction (the forum of a case); choice of law (the law that should apply to resolve the dispute); and recognition and enforcement of foreign judgments. It is a sort of metalaw - a law about law, giving us guidance on the complexities of how we can get to the point where we can apply complex substantive law to resolve a complex dispute. This system of rules is notoriously complicated, but also increasingly important. As law and litigation - mirroring life - became more and more international in recent decades, so too did this area of law increase in its influence; it is a Rosetta stone by which one can determine how one's legal obligations will play out across borders.

For EU member states, these rules have come to be dominated by EU law in recent decades. ${ }^{3}$ Uniform EU rules on jurisdiction and recognition and enforcement, and choice of law in tort and contract, provided a central, stable set of rules across the entire Union, ${ }^{4}$ enabling certainty and predictability in civil and commercial matters. It gave individuals and businesses substantially greater certainty about the way in which international cases might affect them. This uniform European approach

1 See Adrian Briggs, 'Brexit and Private International Law: An English Perspective' (2019) 55(2) Rivista di diritto internazionale privato e processuale 261.

2 See generally Jonathan Hill and Máire Ní Shúilleabháin, Clarkson \& Hill's Conflict of Laws (Oxford University Press 2016).

3 See Geert Van Calster, European Private International Law (3rd edn, Hart 2021) 2.

${ }^{4}$ As we will see, Denmark has been an outlier and late adopter of EU conflicts measures. 
was particularly beneficial for common law countries like Ireland and the UK, when many of our conflict of laws rules - particularly on choice of law in tort in Ireland ${ }^{5}$ and recognition and enforcement of judgments in both jurisdictions ${ }^{6}$ - were very out of date. They were also somewhat chauvinistic, in preferring domestic law and in asserting jurisdiction over disputes, rather than applying foreign law or deferring to foreign courts.

Since the role of EU law in this area is very significant, Brexit upturns private international law in the UK by removing, at a stroke, the most important elements of the pre-Brexit status quo in the field. Despite this, it received little attention during the Article 50 period. Save for a paper from the UK government, ${ }^{7}$ which was quite general, there was little comment on what would happen following Brexit. In the Withdrawal Agreement (WA), we are met with silence when it comes to private international law. The Protocol also adds nothing on this topic. There is no provision for ongoing co-operation in this area, and any arrangement between the EU and the UK on these matters will exist entirely separately from the withdrawal arrangements.

This chapter explains and maps the WA's and the Protocol's perhaps surprising silence on this crucial topic. There is an explanation for the failure to provide for any matters in respect of choice of law: the UK can, and has been able to, adopt a quick fix in domestic law, with no need for EU involvement or reciprocity, that maintains the status quo ante. Jurisdiction and recognition and enforcement of judgments, however, do not admit of any easy or comprehensive answers. It appears that the UK's best chance at minimizing disruption in this area has now been taken off the table by the EU, leaving uncertainty about the future. Time will tell how serious this problem will prove in practice.

${ }^{5}$ While the UK modernized most choice of law in tort rules with the Private International Law (Miscellaneous Provisions) Act 1995, Ireland did not, and the current state of the common law rules is chronically unclear. See Grehan v Medical Incorp. \& Valley Pines [1986] IR 528. The common law position of double actionability required that the tort be fully actionable in the forum as well as actionable in the place of the tort. See Phillips v Eyre (1870) LR 6 QB 1.

${ }^{6}$ Both jurisdictions have declined to follow Canada in modernizing their in personam recognition and enforcement of judgment rules; see David Kenny, 'Re Flightlease: The "Real and Substantial Connection" Test for Recognition and Enforcement of Foreign Judgments Fails to Take Flight in Ireland' (2014) 63(1) International and Comparative Law Quarterly 197.

7 HM Government, 'Handling Civil Legal Cases That Involve EU Countries if There's No Brexit Deal', Technical Notice, 13 September 2018, www.gov.uk/government/publica tions/handling-civil-legal-cases-that-involve-eu-countries-if-theres-no-brexit-deal/hand ling-civil-legal-cases-that-involve-eu-countries-if-theres-no-brexit-deal. 


\subsection{The Rise of EU Conflict of Laws Rules}

For many decades - and accelerating since 2001 - the landscape of private international law in EU member states has been dominated by EU law. Starting with the Brussels Convention of 1968, agreed among the six members of the (then) European Communities but not directly under the rubric of Community law, a common set of rules for jurisdiction and recognition and enforcement was established. ${ }^{8}$ This was primarily to enable free movement of judgments: since recognition and enforcement is largely linked to jurisdiction - we recognize and enforce those judgments the jurisdictional basis of which we endorse - jurisdiction was essentially a means to an end of making member state court judgments mobile across Europe. ${ }^{9}$ If we all apply the same jurisdictional rules in European cases, there should be few obstacles to recognizing and enforcing judgments across Europe. For litigants, however, jurisdiction rules are just as important, as where they will sue and be sued matters a great deal.

Ireland and the UK later joined the Brussels Convention. ${ }^{10}$ In 2001, to make the Brussels Convention rules tighter and reduce regional variance in their application, the rules were set down, in slightly amended form, in an EU Regulation: the Brussels I Regulation, adopted by all members states except Denmark (which did adopt it eventually). ${ }^{11}$ When, in the first decade of its operation, several issues arose, it was recast in 2012 into the Brussels I Bis (Recast) Regulation, ${ }^{12}$ and adopted by all member states, with Denmark opting in to the changes.

Major choice of law rules - the rules that determine what law applies to a case with a transnational element - were also eventually regulated by EU law. Choice of law in contract was regulated by the Rome Convention of 1980, which later was incorporated into EU law in almost identical

8 This was, and continues to be, largely for judgments in personam - to simplify, over people - rather than in rem - over things.

9 The Preamble to the Brussels Convention of 1968 makes it absolutely clear that the priority of the Convention is mobility of judgments. It begins: 'Desiring to implement the provisions of Article 220 of that Treaty by virtue of which they undertook to secure the simplification of formalities governing the reciprocal recognition and enforcement of judgments of courts or tribunals ....'

10 See domestic implementation in Ireland by way of the Jurisdiction of Courts and Enforcement of Judgments (European Communities) Act 1988 and in the UK by means of the Civil Jurisdiction and Judgments Act 1982.

11 Regulation 44/2001/EC. Denmark adopted the 2001 Regulation in 2007 and the 2012 Regulation in 2015.

12 Regulation 1215/2012/EC. 
terms in the Rome I Regulation. ${ }^{13}$ Choice of law in most tort matters (notably not defamation ${ }^{14}$ ) was regulated by the Rome II Regulation, ${ }^{15}$ which had no convention predecessor, and at the time was somewhat controversial in respect of the competence of the EU to act in this area at all. $^{16}$

With these measures, the vast majority of civil and commercial conflict cases were governed by EU law rules. This uniformity meant that those engaged in commercial activity in the EU were not subject to the vicissitudes of different member states' (highly varied) domestic conflict rules. In particular, the Brussels regime harmonizing jurisdiction rules at an EU level massively increased the predictability of litigation and the mobility of judgments, eliminating - for EU domiciliaries at least ${ }^{17}$ - the various and often problematic national jurisdictional rules to which they would be subject. It also ensured that irreconcilable conflicting judgments from different member states would be unlikely, since all states should be applying the same consistent set of rules. Where this was not the case, it provided for rules of priority. ${ }^{18}$

\subsection{The Effect of Brexit}

The UK adopted all of these EU Regulations while a member of the Union, and was a beneficiary of the legal certainty and the free movement of judgments that they enabled. With Brexit, these Regulations ceased to apply in the UK from the end of the transition period; cases started on or after 1 January 2021 would not be able to avail of the EU rules. Little attention was paid to this during the transition period or negotiations on the WA, and the WA and the Protocol are essentially silent on these issues. When it comes to the two choice of law instruments - Rome I and

13 Regulation 593/2008/EC.

14 See Liz Heffernan and David Kenny, 'Defamation and Privacy and the Rome II Regulation' in Peter Stone and Youseph Farah (eds), Research Handbook on the Conflict of Laws (Edward Elgar 2015) 315.

${ }_{15}$ Regulation 864/2007/EC.

16 See discussion in the EU Committee of the House of Lords, 'The Rome II Regulation' HL Paper 66/2004. The subsequent competence around European citizenship included in the Treaty of Lisbon made this argument otiose, as the citizenship competence is seen to cover tort liability and other personal legal matters.

17 National jurisdiction rules persist for application to any non-EU domiciliaries and cases that fall outside the scope of the Regulation. See Art 6 Brussels I (Recast) Regulation 1215/ 2012/EC.

18 See Recital 21 and Arts 8 and 30 Brussels I (Recast) Regulation 1215/2012/EC. 
Rome II - an easy solution is available outside the EU framework. However, with jurisdiction and recognition and enforcement, there is no such solution available, and thus there was no obvious way that the WA could have solved this problem.

The choice of law rules contained in Rome I and Rome II were not a problem because they are universal. ${ }^{19}$ They apply the same way to European domiciliaries and cases as to non-European domiciliaries and cases: these rules will apply the law of Guam just as readily as the law of Germany; neither of the parties before the court must be a domiciliary of a member state in order for the rules to apply. They apply to every case that falls within their subject matter scope, and no EU connection is needed. Intimately related to this is the fact that these rules do not require any reciprocity whatsoever: they do not require or expect that the courts of Guam apply the same conflict rules as EU states do, and from a conflict point of view, nothing turns on whether or not they do. Though the regulations are EU rules, then, they do not have to be EU rules in order to work: third states could adopt identical rules in their domestic law and have the same effects in conflict cases, even though they are outside the EU law framework.

This, essentially, is what the UK has done. In the Law Applicable to Contractual Obligations and Non-contractual Obligations (Amendment etc) (EU Exit) Regulations 2019, ${ }^{20}$ the UK retained, mutatis mutandis, both the Rome I and the Rome II Regulations as part of domestic UK law. The changes are exceptionally minor, and relate to no more than adapting the language of the Regulations to apply to the UK rather than to a member state of the EU. Therefore, Brexit effects no change on choice of law rules in the UK in practice, and the system that was present the day before the transition period ended was seamlessly replaced by, effectively, an identical system.

Jurisdiction and recognition and enforcement, however, are very different, because they are not universal: the rules apply very differently to EU and non-EU domiciliaries and cases. The whole scheme of the Brussels I Regime is founded on mutuality and reciprocity: the rules are designed to ensure that EU member states are applying the same set of jurisdictional rules to all cases involving EU domiciliaries. Member states defer jurisdiction to other member states based on the assumption that that state is also applying these same rules; the resolution of jurisdiction

19 See Art 2 Rome I Regulation 593/2008/EC; Art 3 Rome II Regulation 864/2007/EC.

20 Statutory Instrument 2019 No 834. 
questions is, in principle, uniform. ${ }^{21}$ Based on this assumption, the Regime makes recognition and enforcement of judgments of EU courts effectively automatic, with only the most limited exceptions. ${ }^{22}$ There is no need to doubt the judgment of any court of an EU member state because the soundness of its jurisdictional basis is secure, since the court has properly applied the EU rules. ${ }^{23}$

This means that there is no scope for non-member states to join the Brussels Regime in its form as a Regulation. The process by which Regulations are automatically implemented in domestic law, which eliminates much of the discretion enjoyed by member states under prior jurisdiction rules, ${ }^{24}$ was designed to work only within the EU legal order where reciprocity can be reliably expected. It also means that a nonEU state cannot simply import the rules into its domestic law. The system works only if both states that are applying the same rules recognize each other's application of the rules for the purposes of recognizing judgments and deferring to the other's jurisdictional claims. Applying the rules domestically without being part of the broader EU system would be meaningless, and so the solution that worked for Rome I and Rome II was simply impossible for Brussels I.

The focus on reciprocity, trust and co-operation that undergirds the Brussels Regime, and its reliance on the mechanisms of EU law in order to work, also meant that Brexit would inevitably result in the UK's exit from this framework. The only question was what could be done to minimize the impact of this. Minimizing this impact is obviously extremely important. Far more than choice of law, ${ }^{25}$ jurisdiction and recognition and enforcement questions are crucial to commercial actors planning their affairs, as well as to anyone considering litigation in the UK, and they would be rendered far more uncertain by Brexit. But it was

${ }^{21}$ See, eg, discussion of Clarke J in Goshawk Dedicated Ltd $v$ Life Receivables Ireland Ltd [2008] IEHC 90.

22 See Arts 45-51 Brussels I (Recast) Regulation 1215/2012/EC.

${ }^{23}$ However, the enforcing court cannot actually be sure of this, and, indeed, even if it is sure that they have not applied the rules or have not applied them correctly, the enforcing court cannot refuse to enforce on this basis: see Bamberski v Krombach Case C-7/98.

${ }^{24}$ For example, the common law doctrine of forum non conveniens allowed common law courts to simply decline jurisdiction if it was determined that there was a better forum elsewhere; this was not permitted under Brussels. Case C-281/02, Owusu v Jackson [2005] ECR I-1383.

${ }^{25}$ For example, Geert Van Calster, prominent scholar and practitioner of private international law, says that no client of his has ever hesitated to enter a market because of uncertainty about choice of law in tort. See Van Calster (n 3) 294. 
apparent that there is no easy solution, and the WA's and the Trade and Cooperation Agreement (TCA)'s silence on the matter - and its apparent absence from the negotiations on either agreement - meant that the UK would be left to try to find some workable arrangement outside of that framework. Though membership of the Brussels regulations would not have been something that could have been negotiated in the WA, the second-best solution - the EU supporting the UK's accession to the Lugano Convention - might have been, but was not, negotiated as part of the TCA. As we shall see, that option now appears to be off the table.

\subsection{Options for the UK on Jurisdiction/Recognition and Enforcement}

There were several theoretical alternatives for the UK's approach to jurisdiction after Brexit. One of these was never practically possible; one was possible but, it seems, will not happen due to the EU's unwillingness to allow it; one has borne fruit, and at least made the problem less bad.

\subsubsection{The Old Convention}

An early suggestion for how to address jurisdiction after Brexit was that the UK could, perhaps, revert to its membership of the old Brussels Convention, which persisted even after the advent of the Regulation for certain territories of member states that were not part of the Union. This would not have been a perfect solution - it is less strict than the Regulations that replaced it, and thus less predictable, and it lacks the various improvements that the 2001 and 2012 Regulations introduced. However, the UK had left the Convention upon accession to the 2001 Regulation, and could not rejoin since the Convention survived only for a limited number of territories of member states where EU law did not apply at the time that the Brussels regime transitioned to EU regulation. This option was never a viable one.

\subsubsection{The Lugano Convention}

The Lugano Convention ${ }^{26}$ (first 1988, later 2007) is a Convention very similar to the Brussels Regime, designed to provide a similar set of rules

${ }^{26}$ See generally Fausto Pocar, 'The New Lugano Convention on Jurisdiction and the Recognition and Enforcement of Judgments in Civil and Commercial Matters' (2008) 10 Yearbook of Private International Law 1. 
for the EU and European Free Trade Association (EFTA) members, and other territories that had been parties to the old Convention. It replicates to a significant degree the rules in the 2001 Regulation for both jurisdiction and recognition and enforcement. Membership of the Lugano Convention would substantially bridge the gap left by the non-application of Brussels I, although it would not do so completely. Lugano does not incorporate the changes made in the 2012 Recast, including fixes for third state litigation, ${ }^{27}$ the Italian Torpedo, ${ }^{28}$ and even easier recognition and enforcement of judgments. ${ }^{29}$ It is also less strict, with no recourse to the Court of Justice of the European Union (CJEU). But it would be the closest the UK could get to the pre-Brexit rules, and accession to it would have meant less uncertainty and disruption.

The Lugano Convention is, in principle, open to any state. However, accession to Lugano requires the consent of all contracting parties, one of which is the EU. The UK applied to accede on 8 April 2020. There is a oneyear period for existing parties to decide on an application. There were various conflicting reports about what the EU might do, but on 4 May, the EU Commission recommended the rejection of the UK's application, a recommendation that is likely to be followed. The Commission's approach to the issue makes it relatively clear that the UK will never be allowed to accede to the Convention: the Convention is seen as an adjunct to the EFTA/European Economic Area (EEA), and essentially part of the legal basis of these areas and the Union's economic relations with those states which have close regulatory alignment with the EU. States outside of this framework are thus not sufficiently aligned with the EU to be members of the Convention. ${ }^{30}$ Thus, although the Convention is not explicitly limited to EFTA/EEA states, the Commission's view means that, in practice, it is now and will continue to be seen to be so. Given the unwillingness of the UK to enter into close regulatory alignment of an EFTA/EEA type, it is apparent that UK membership of Lugano will not be possible as long as the UK

27 See Arts 33 and 34 Brussels I (Recast) Regulation 1215/2012/EC.

28 The Italian Torpedo was a litigation tactic that used the priority rules in the Brussels Regime and the lack of expedition of the Italian courts to cause long delays in cases being heard by the appropriate EU court. The Recast seeks to address this, but with some issues. See Art 31.2 Brussels I (Recast) Regulation 1215/2012/EC; David Kenny and Rosemary Hennigan, 'Choice-of-Court Agreements, the Italian Torpedo, and the Recast of the Brussels I Regime' (2015) 64(1) International and Comparative Law Quarterly 197.

29 Arts 36-44 Brussels I (Recast) Regulation 1215/2012/EC.

30 Shane McVeigh, 'EU Rejects UK Re-entry to Lugano Convention' (13 May 2021) www.carsonmcdowell.com/news-and-events/insights/eu-rejects-uk-re-entry-to-lugano-convention. 
retains its current stance. It is possible, perhaps, that Northern Ireland which does have regulatory alignment of this type - might be able to apply to join Lugano. But for the UK in general, it seems clear that the EU Commission sees the way forward as being the Hague Convention on Choice of Court Agreements. ${ }^{31}$

\subsubsection{The Hague Convention on Choice of Court Agreements 2005}

The best solution now available is the Hague Convention on Choice of Court Agreements. This Convention came into force in 2015 after the EU acceded to it. It also includes Israel, Mexico, Montenegro and Singapore. The Hague Convention provides for the recognition of choice of court/ jurisdiction agreements that nominate one of the contracting states as the proper forum for an action arising among the parties to the agreement. The agreement must be exclusive - only the court of one contracting state can hear that case. Other contracting states agree to honour such an agreement by deferring to the court nominated in the agreement, and agree not to hear any action unless and until that court declines jurisdiction. A judgment given on the basis of a jurisdictional claim under the Convention should be recognized and enforced in another Convention state.

The UK is now a member of the Hague Convention in its own right. This means that exclusive jurisdiction agreements nominating the UK or an EU state will be recognized in the other, and thus any judgment that is given on foot of such an agreement from a UK or EU court will be recognized in the other place. This is no small thing, as commercial actors will usually wish to regularize jurisdiction by agreement. The nature of the requirements for such an agreement is broadly similar to Brussels I.

However, there are a number of limitations to the Hague Convention. First, it solves the problem only for jurisdiction agreements that are valid under the Convention; no other jurisdiction issues, that are not subject to agreement, are resolved. Second, it allows only for exclusive jurisdiction agreements; many parties wish to have more than one possible jurisdiction, or asymmetric clauses - common in finance contracts - which allows for different choices for different parties to the agreement. None of this is possible under the Convention. ${ }^{32}$ Third, there are outstanding questions about how the Convention will overlap with agreements under

31 Clifford Chance, 'Commission Rejects UK Application to Join Lugano' (May 2021) www .cliffordchance.com/content/dam/cliffordchance/briefings/2021/05/commission-rejectsuk-application-to-join-lugano.pdf.

32 Ibid. 
the Brussels I Recast and whether there will be any problems with this. These issues aside, however, UK accession to the Hague Convention is an important step towards bridging the gap left by Brexit.

\subsection{Conclusion}

The Hague Convention is a reasonable solution for most commercial actors who will have the opportunity to make a choice of court agreement, giving some security as to both jurisdiction and enforcement. But not all cases will involve choice, and not all those subject to international litigation are savvy commercial actors. For this category of cases, with no chance of Lugano Convention accession, the situation is less rosy. If all else fails, the UK's common law rules of jurisdiction - based on service and territoriality - and its (perhaps outdated) ${ }^{33}$ rules of recognition and enforcement will be used to decide jurisdiction. These common law rules continued to apply to non-Brussels I cases, involving non-EU domiciliaries, during the period of the UK's EU membership and will now extend to all cases not covered by the Hague Convention. These are not an optimal fallback in terms of mobility of judgments, as few other states use this approach to jurisdiction, and this may cause difficulties in invoking the exequatur process of various European courts, which are, of course, not uniform. ${ }^{34}$ Ireland and Northern Ireland, having very nearly identical rules of jurisdiction and recognition and enforcement of judgments, should have fewer problems with mobility of judgments, given that recognition is so dependent on similarity of jurisdiction rules. However, UK enforcement rules may pose challenges for EU member state judgments if their jurisdiction basis does not match the narrow rules for common law enforcement. It is thus not clear that recognition and enforcement of judgments of EU member state courts in the UK, and UK judgments in the EU, will be easy if the common law rules remain the predominant approach to jurisdiction after Brexit.

33 The rules of recognition and enforcement for judgments in personam are based on an old theory known as the doctrine of obligation, which does not account for twentieth-century developments in UK jurisdiction, such as service outside of jurisdiction and forum non conveniens. Briggs, however, defends this approach: Adrian Briggs, 'Recognition of Foreign Judgments: A Matter of Obligation' (2013) 129 Law Quarterly Review 87.

34 For some detail on different enforcement regimes, see Clifford Chance, 'How English Judgments Will Be Enforced in the EU Post-Brexit' (May 2021) www.cliffordchance.com/ content/dam/cliffordchance/briefings/2021/05/how-english-judgments-will-be-enforced-inthe-eu-post-Brexit.pdf. 
